\title{
Device simulation of perovskite solar cells with molybdenum disulfide as active buffer layer
}

\author{
Ainon Shakila Shamsuddin ${ }^{1}$, Puteri Nor Aznie Fahsyar ${ }^{2}$, Norashikin Ahmad Ludin ${ }^{3}$, Ibrahim Burhan ${ }^{4}$, \\ Salina Mohamad ${ }^{5}$ \\ ${ }^{1,5}$ Departement of Electrical Engineering, KDU University College Sdn Bhd, Malaysia \\ ${ }^{2,3}$ Solar Energy Research Institute (SERI), Universiti Kebangsaan Malaysia, Malaysia \\ ${ }^{4}$ Department of Aircraft Maintenance, Politeknik Banting Selangor, Malaysia
}

\begin{tabular}{l}
\hline \hline Article Info \\
\hline Article history: \\
Received Mar 29, 2019 \\
Revised May 25, 2019 \\
Accepted Jun 28, 2019 \\
\hline
\end{tabular}

\section{Keywords:}

Active layer

Device simulation

$\mathrm{MoS}_{2}$

Perovskite

Solar cells

\begin{abstract}
Organo-halide Perovskite Solar Cells (PSC) have been reported to achieve remarkably high power conversion efficiency (PCE). A thorough understanding of the role of each component in solar cells and their effect as a whole is still required for further improvement in PCE. In this paper, the effect of Molybdenum Disulfide $\left(\mathrm{MoS}_{2}\right)$ in PSC with mesoporous structure configuration was analyzed using Solar Cell Capacitance Simulator (SCAPS). With the $\mathrm{MoS}_{2}$ layer which having two-fold function, acting as a protective layer, by preventing the formation of shunt contacts between perovskite and Au electrode, and as a hole transport material (HTM) from the perovskite to the Spiro-OMETAD. As simulated, PSC demonstrates a PCE, $\eta$ of $13.1 \%$, along with stability compared to typical structure of PSC without $\operatorname{MoS}_{2}(\Delta \mathrm{y} / \mathrm{y}=-9 \%$ vs. $\Delta \mathrm{y} / \mathrm{y}=-6 \%)$. The results pave the way towards the implementation of $\mathrm{MoS}_{2}$ as a material able to boost shelf life which very useful for new material choice and optimization of HTMs.
\end{abstract}

Copyright $@ 2019$ Institute of Advanced Engineering and Science. All rights reserved.

\section{Corresponding Author:}

Ainon Shakila Shamsuddin,

Department of Electrical Engineering,

KDU University College Sdn Bhd.,

Jalan Kontraktor U1/14, seksyen U1,

Glenpark U1, 40150, Shah Alam Selangor, Malaysia.

Email: ainon.s@kdu.edu.my

\section{INTRODUCTION}

Solid-state organo-metal halide perovskite solar cells (PSCs) have been developed as promising alternatives to existing solution-processed photovoltaic technologies [1-4]. The methylammonium iodide, $\mathrm{MaI}\left(\mathrm{CH}_{3} \mathrm{NH}_{3} \mathrm{PbI}_{3}\right)$ is one of the most ample light-harvesting material, mainly due to its direct bandgap, high absorption coefficient and long exciton diffusion length [5]. Despite the impressive photovoltaic performance with power conversion efficiency (PCE) beyond 22\%, PSCs' operational stability and the material toxicity is endure the crucial concern.

To achieve higher efficiency, the understanding of device mechanism is important. Due to this reason, device simulation is useful and brought the conventional solar cells based on inorganic semiconductor such as silicon, $\mathrm{CdTe}, \mathrm{Cu}(\mathrm{In}, \mathrm{Ga}) \mathrm{Se}_{2}$ (CIGS) and $\mathrm{Cu}_{2} \mathrm{SnZn}\left(\mathrm{S}_{2} \mathrm{Se}_{4}\right)$ were widely analysed using device simulator [6-9]. Up to now, there are a few reports been concerning on the numerical simulation of the perovskite-based solar cells [10-12]. However, the detailed theoretical analysis of the stability of PSCs using device simulation is not extensively studied. The perovskite material are organic-inorganic hybrid materials and have similar material properties with inorganics materials especially low binding energy of exciton, and thus the exciton is Wannier type. Also, the device structure of the PSCs and inorganics thin film 
solar cells is similar. The typical structure for the PSCs is TCO/BL/absorber/HTM/contact and that of CIGS solar cells is TCO/buffer/absorber/contact.

A further substantial limitation on view of the possible commercialization is their lifetime stability which adversely affected by the presence of the Spiro-OMETAD [13]. This is due to the fact that Spiro-OMETAD in its pristine form (amorphous), which has low conductivity, $\sigma$ [14]. Another factor limiting the device stability is the interface created by the Spiro-OMETAD and the perovskite layer [12-13]. Analysis done by [15] reported indication of iodine migration from the perovskite layer to Spiro-OMETAD and degraded the cell efficiency. Slow transient effects causing hysteresis in the current-voltage characterization can lead to an over-or underestimation of the solar cell device efficiency [16]. Subsequent, the direct contact between the perovskite and the metal electrode shows the high recombination losses which decreased the open-circuit voltage, Voc and Fill Factor value [17]. One strategy to minimize the effect could be to increase the hole transport layer thickness, however it will results in increasing the PSCs series resistance, which reduced the cell efficiency [18]. The addition of mesoporous Aluminium oxide, $\mathrm{Al}_{2} \mathrm{O}_{3}$ layer in between the perovskite and Spiro-OMETAD to prevent shunting pathway as a passive protection function [19].

\section{METHOD}

In this paper, device simulation are performed by using Solar Cell Capacitance Simulator (SCAPS). The device simulator, SCAPS was developed by University of Gent [20] and it is used to model the PSCs. $\mathrm{MoS}_{2}$ layer is inserted in PSCs with $\mathrm{FTO} / \mathrm{TiO}_{2} / \mathrm{CH}_{3} \mathrm{NH}_{3} \mathrm{PbI}_{3} /$ Spiro-OMETAD structure to create an active buffer layer. There will be a two functions of this layer which are barrier towards the metal electrode migration and additional energy matching layer for the further ease the hole collection of the Spiro-OMETAD. First, the validity of device modelling was confirmed by the comparison with real device. Then, the insertion of $\mathrm{MoS}_{2}$ layer in between the perovskite and Spiro-OMETAD was modelled to examine the stability of the PSCs. Device characteristics under various condition can be studied through theoretical analysis of solar cell.

\section{DEVICE SIMULATION PARAMETERS}

The device simulator SCAPS Version 3.3.07 was used as a simulation platform. PSCs employed in the simulation is a solid-state $n-i-p$ structure with intrinsic perovskite material sandwiched between $n$-type TiO2 and p-type Spiro-OMeTAD (2,2',7,7'- tetrakis (N,N-di-p-methoxyphenylamine) -9,9' spirobifluorene) material. Spiro-OMeTAD is applied as the hole transport material (HTM). $\mathrm{SnO}_{2}: \mathrm{F}$ (FTO) is the transparent conductive oxide (TCO) and Au serves as a contact as shown in Figure 1(a). Figure 1(b) it shows the structure with $\mathrm{MoS}_{2}$ layer in between perovskite and Spiro-OMETAD. Compared to the typical structure, two hypothetical interface defect layers, i.e. $\mathrm{TiO}_{2} /$ perovskite layer (IDL1) and perovskite/HTM layer (IDL2), are inserted into the model to consider the recombination on the interfaces. Note that some parameters are very difficult to determine, thus, some reasonable value was estimated. For all layers, the effective density of states of conduction band $\mathrm{Nc}$, the effective density of states of valence band $\mathrm{Nv}$, and the thermal velocity, $\mathrm{Nt}$, are set as $2.2 \times 10^{18} \mathrm{~cm}-3,1.8 \times 10^{19} \mathrm{~cm}^{-3}$ and $10^{7} \mathrm{~cm} / \mathrm{s}$, respectively. The absorption coefficient is set to be $10^{5} \mathrm{~cm}^{-1}$ to simplify the model. Defect type is neutral and the capture cross section is $2 \times 10^{-14} \mathrm{~cm}^{2}$.

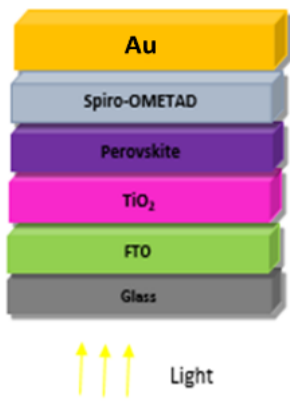

(a)

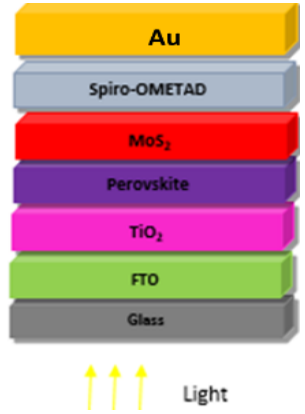

(b)

Figure 1. Device structure, (a) $\mathrm{FTO} / \mathrm{TiO}_{2} / \mathrm{CH}_{3} \mathrm{NH}_{3} \mathrm{Pbl}_{3} /$ Spiro OMERTAD, (b) $\mathrm{FTO} / \mathrm{TiO}_{2} / \mathrm{CH}_{3} \mathrm{NH}_{3} \mathrm{Pbl}_{3} / \mathrm{MoS}_{2} /$ Spiro-OMERTAD 
Table 1 summarizes the base parameter set of each layer in simulation. Here, NA and ND denote acceptor and donor densities, $E r$ is relative permittivity, $\chi$ is electron affinity, Eg is band gap energy, $\mu$ n and $\mu \mathrm{p}$ are mobility of electron and holes. The thickness of each layer were taken from an experimental that report high efficiency PSCs [21]. Pre-factor A $\alpha$ was 105 to obtain absorption coefficient $\alpha$ calculated by $\alpha=\mathrm{A} \alpha$ (hv-Eg) $1 / 2$. Energetic distribution is Gaussian, and the characteristic energy is set to be $0.1 \mathrm{eV}$. The default illumination spectrum is set to the global AM1.5 standard and the default operation temperature is set to $300 \mathrm{~K}$. The optical reflectance at the surface and interfaces of each layer is not considered in this work. The validity of the device simulation is to compared and confirmed with the real devices performance reported by literature to demonstrate the reliability. With the default parameters, we get the result of $\mathrm{Jsc}=21.68 \mathrm{~mA} / \mathrm{cm}^{2}$, $\mathrm{Voc}=0.97 \mathrm{~V}, \mathrm{FF}=0.66$ and $\mathrm{PCE}=13.93 \%$, which is similar with the experimental results reported in literature [22].

Table 1. Input parameter for device simulation

\begin{tabular}{lcccccc}
\hline \multicolumn{1}{c}{ Parameter } & $\mathrm{FTO}$ & $\mathrm{TiO}_{2}$ & $\mathrm{IDL} 1$ & $\mathrm{CH}_{3} \mathrm{NH}_{3} \mathrm{PbI}_{3}$ & IDL2 & $\mathrm{HTM}$ \\
\hline Thickness $(\mathrm{nm})$ & 500 & 50 & 10 & 350 & 10 & 400 \\
Bandgap, $\mathrm{E}_{\mathrm{g}}(\mathrm{eV})$ & 3.5 & 3.2 & 1.55 & 1.55 & 1.55 & 3 \\
Electron affinity, $\chi(\mathrm{eV})$ & 4 & 4 & 3.9 & 3.9 & 3.9 & 2.05 \\
Dielectric permittivity, $\varepsilon_{\mathrm{r}}$ & 9 & 100 & 6.5 & 6.5 & 6.5 & 3 \\
$\mathrm{~N}_{\mathrm{c}}\left(\mathrm{cm}^{-3}\right)$ & $2.2 \times 10^{18}$ & $2.2 \times 10^{18}$ & $2.2 \times 10^{18}$ & $2.2 \times 10^{18}$ & $2.2 \times 10^{18}$ & $2.2 \times 10^{18}$ \\
$\mathrm{~N}_{\mathrm{v}}\left(\mathrm{cm}^{-3}\right)$ & $1.8 \times 10^{19}$ & $1.8 \times 10^{19}$ & $1.8 \times 10^{19}$ & $1.8 \times 10^{19}$ & $1.8 \times 10^{19}$ & $1.8 \times 10^{19}$ \\
Electron mobility, $\mu_{\mathrm{n}}\left(\mathrm{cm}^{2} / \mathrm{Vs}\right)$ & 20 & 0.006 & 2 & 2 & 2 & 0.0001 \\
Hole mobility, $\mu_{\mathrm{p}}\left(\mathrm{cm}^{2} / \mathrm{Vs}\right)$ & 10 & 0.006 & 2 & 2 & 2 & 0.0001 \\
\hline
\end{tabular}

\section{RESULTS AND DISCUSSION}

Devices such as solar cells, charge generation, disconnection and transportation actively contribute in the performance of the prepared perovskite solar cells. Therefore, engineering the energy band diagram, materials selection, and physical properties of materials would control the perovskite solar cells efficiency [23-25]. Figure 2 shows the structure of the prepared device from SCAPS simulation and the energy band diagrams of $\mathrm{FTO} / \mathrm{TiO}_{2} / \mathrm{CH}_{3} \mathrm{NH}_{3} \mathrm{Pbl}_{3} / \mathrm{MoS}_{2} /$ Spiro-OMeTAD. Device configuration shows in Figure $2(\mathrm{a})$ is the $3 \mathrm{~nm}$ compact layer of $\mathrm{MoS}_{2}, 350 \mathrm{~nm}$ perovskite layer, $50 \mathrm{~nm} \mathrm{TiO}$ thin film and the metal contact layer with $10 \mathrm{~nm}$ thickness. As shown in Figure 2(b) the generated electron can easily transfer to $\mathrm{TiO} 2$ layer because of the high electron affinity of $\mathrm{TiO}_{2}$ at the interface of $\mathrm{TiO}_{2}$ and perovskite layer while $\mathrm{MoS}_{2}$ layer can collect the generated holes.

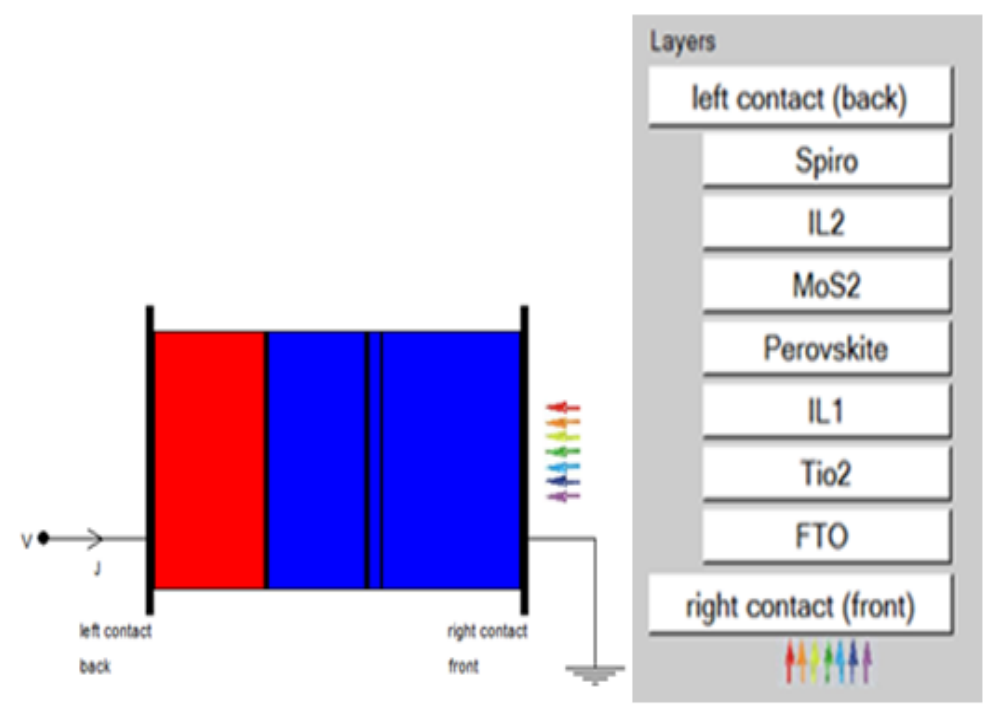

(a) 


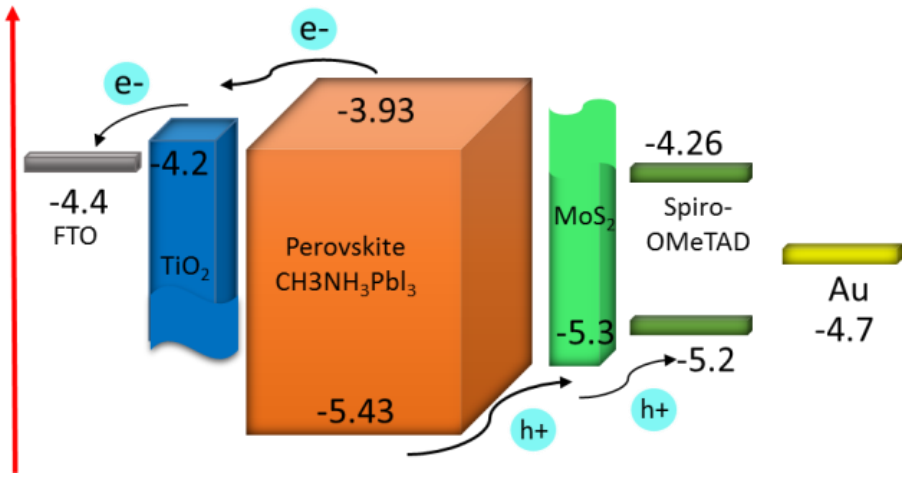

(b)

Figure 2. Structure of the prepared device from SCAPS simulation and the energy band diagrams, (a) Device structure preparation in SCAPS simulation, (b) Energy level diagrams for

FTO/TiO $2 / \mathrm{CH}_{3} \mathrm{NH}_{3} \mathrm{Pbl}_{3} / \mathrm{MoS}_{2} /$ Spiro-OMeTAD

\subsection{Effect of the bandgap and thickness layer of the absorber}

Figure 3 shows the variation of Voc, Jsc, FF and $\mathrm{y}$ depending on the bandgap energy of the perovskite layer. The PSCs with $\mathrm{Eg}=1.3,1.4,1.5$ and $1.6 \mathrm{eV}$ do not exhibits large differences in increasing Voc from $0.925 \mathrm{~V}$ to $1.067 \mathrm{~V}$. However, Jsc, FF and $\mathrm{n}$ are found to be decreased with the increasing value of Eg. In detail comparison, Jsc decreased from $29.235 \mathrm{~mA} / \mathrm{cm}^{2}$ to $18.433 \mathrm{~mA} / \mathrm{cm}^{2}$, FF reduced from $83.65 \%$ to $59.87 \%$ meanwhile the $\mathrm{y}$ reduced from $22.63 \%$ to $11.78 \%$.
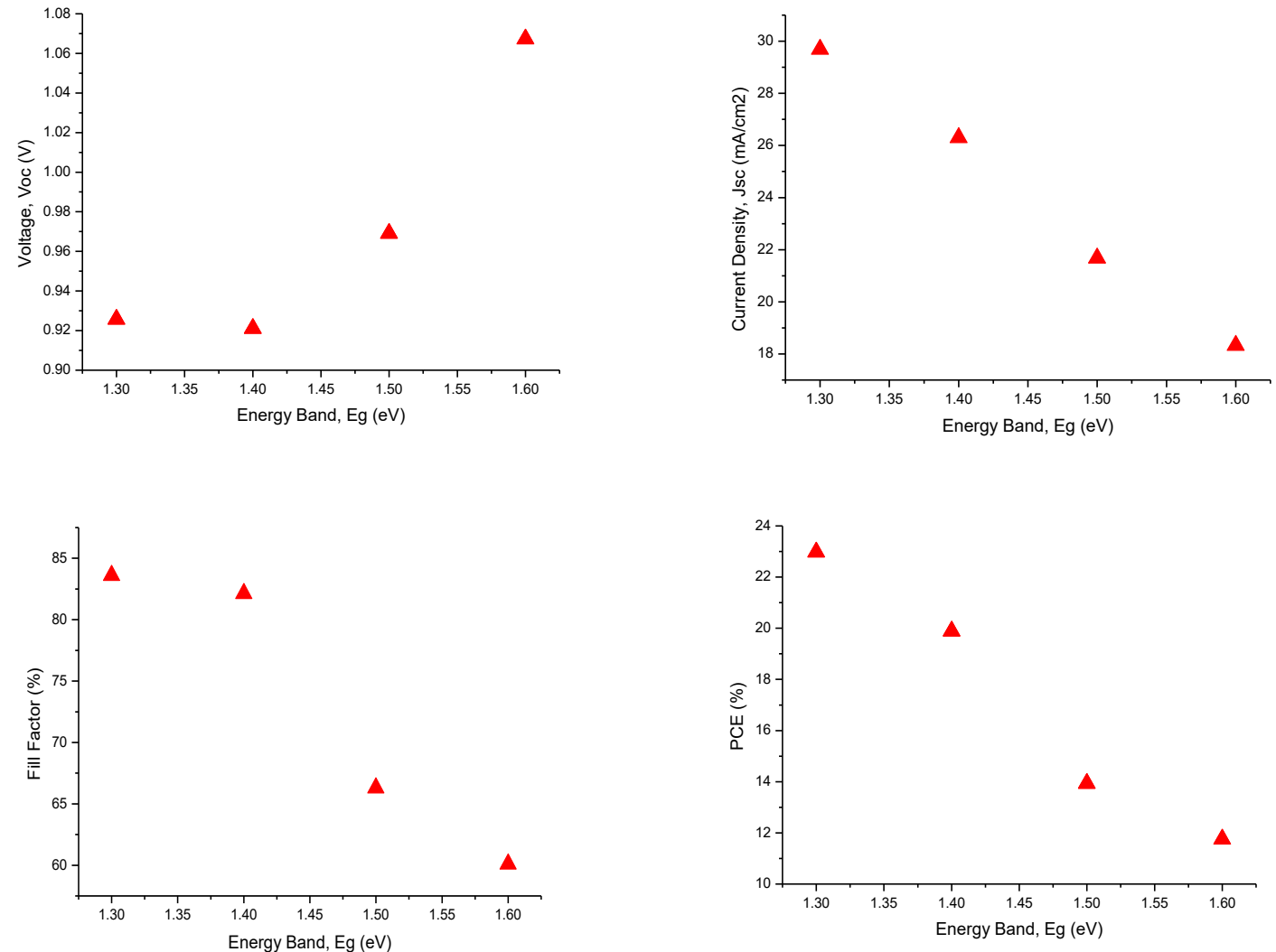

Figure 3. Variation of Voc, Jsc, FF and PCE depending on the bandgap energy of perovskite layer 
Figure 4 shows the effect of the thickness of the perovskite layer on solar cell performance. For the structure with $\mathrm{MoS}_{2}$, the optimum thickness of the perovskite layer is approximately $350 \mathrm{~nm}$. At the thickness for the best Jsc, FF slightly decreased. For the typical structure without $\mathrm{MoS}_{2}$, the optimum thickness is $500 \mathrm{~nm}$. At the optimum thickness, the Voc and Jsc are almost same for the both structures because of the current matching. However, FF shows the very large difference at the optimum perovskite layer thickness. In detail comparison with typical structure of PSCs, the cells with $\mathrm{MoS}_{2}$ buffer layer show a decrease in Voc $(0.969 \mathrm{~V}$ vs. $0.982 \mathrm{~V})$ and FF (66.3\% vs. $61.7 \%)$. However, Jsc is found to remain unchanged $21.68 \mathrm{~mA} / \mathrm{cm}^{2}$ bringing the $\mathrm{y} 13.13 \%$ from $13.93 \%$ of the cell without $\mathrm{MoS}_{2}$.

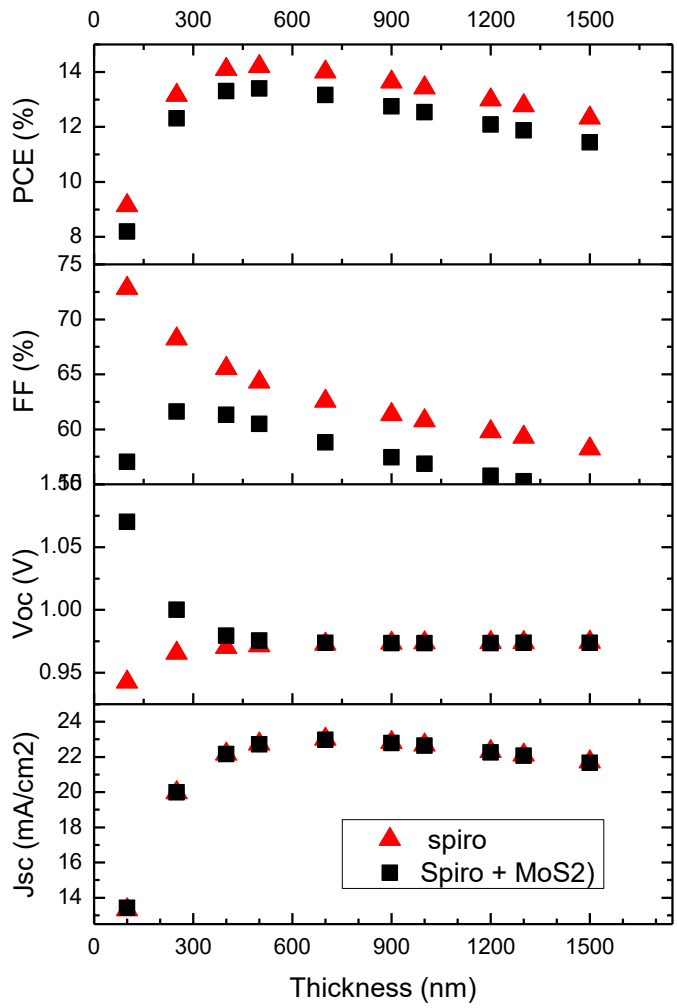

Figure 4. The effect of thickness of the perovskite layer for both structure

The increasing thickness leads to more light absorption and more additional carrier concentration, which brings the values of $\mathbf{J}_{\mathrm{sc}}$ to elevate. Since perovskite material has very high absorption coefficient, normally up to $10^{5} \mathrm{~cm}^{-1}$, the cell can achieve very high values of $J_{\mathrm{sc}}$ and $\mathrm{y}$ for very thin absorbers. $\mathrm{V}_{\text {oc }}$ can be defined by (1):

$$
V_{o c}=\frac{n k T}{q} \ln \left(\frac{I_{L}}{I_{o}}+1\right)
$$

where $\mathrm{n}$ is a factor, $k T / q$ is the thermal voltage, $\mathrm{I}_{\mathrm{L}}$ is the light generated current, and Io is the dark saturation current. More additional carriers concentration gives higher value of $\mathrm{I}_{\mathrm{L}}$, while Io stays at low level because of not much recombination in the cell. This is the reason why $\mathrm{V}_{\mathrm{oc}}$ increases innitialy.

The FF can be defined as the ability to deliver the available power to a load among the maximum power generated by a cell or the internal power reduction. Even though the $\mathrm{y}$ is increasing with the thickness increasing when the thickness is less than $700 \mathrm{~nm}$, the internal power reduction is also increasing, causing a total decrease of the FF. The increase of $y$ is a compromise of weakening the power delivering ability. While the thickness is high, more and more recombination happens because of the increasing number of traps and because more and more additional carriers are not be able to reach the electrodes. In this case, thicker absorber brings the FF, $\mathrm{V}_{\mathrm{oc}}$ and $\mathrm{y}$ to decrease. Thus, it can be concluded in this simulation, the performance 
of a solar cell is controlled by two factors, photon absorption and carrier transport. Photon absorption is the determinant for thin absorber and carrier transport is the determinant for thick absorber, the Save As command, and use the naming convention prescribed by your conference for the name of your paper. In this newly created file, highlight all of the contents and import your prepared text file. You are now ready to style your paper; use the scroll down window on the left of the MS Word Formatting toolbar.

\subsection{Effects of the interface defect density}

The intersection quality of the interface layers is very important to the cell performance. The defect layers might degrade the quality and cause high recombination. Due to the difficulty in approximation ot the recombination caused by the interface defects, the hypothetical defect layers are inserted to represent the interface defects. IDL1 stands for $\mathrm{TiO}_{2}$ /perovskite interface and IDL2 stands for perovskite/HTM interface. The defect densities can determine the recombination on the interfaces. In the simulation, the defect density of IDL1 and IDL2 was varied from $10^{13}$ to $10^{21} \mathrm{~cm}^{-3}$, respectively. Other parameters remain default. The results are shown in Figure 5.

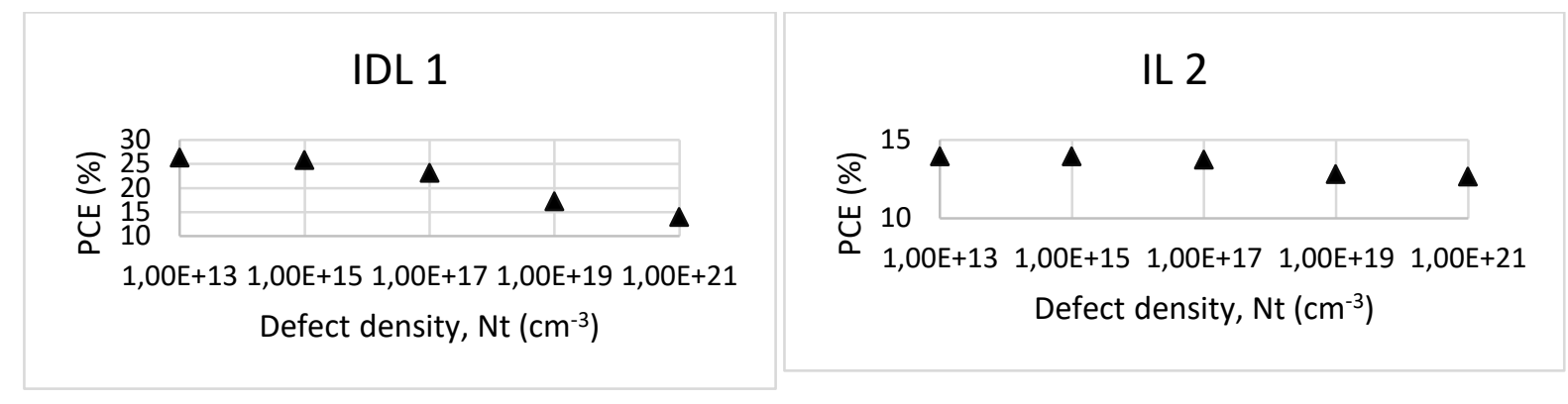

(a)

(b)

Figure 5. Different defect densities in the conditions of, (a) changing IDL1, and (b) changing IDL2

The results show that the defect density on the $\mathrm{TiO}_{2}$ /perovskite interface affects strongly on the performance (higher values of Jsc, Voc and PCE at lower defect density levels). Equally, the defect density on the perovskite/HTM interface has mild impact on the performance. The increase of defect density will certainly increase the number of traps in the cells, which will cause more recombination, and then the performance will become worse. However, the effect of IDL1 is much stronger than IDL2, the reason is that under illumination, the number of electron-hole pairs generated at the irradiation side (front side) of absorber are much higher (reaching ten times) than that at the back side. That is, the additional carrier density is higher at front side, leading to greater recombination rate on front interface. Therefore, the front interface $\left(\mathrm{TiO}_{2}\right.$ /perovskite) has stronger influence on device performance than the back interface (perovskite/HTM). In this case, during the fabrication process of PSCs, it is better to focus on the $\mathrm{TiO}_{2} /$ perovskite interface instead of the perovskite/HTM interface, by improving the quality of the illuminating side interface to decrease the defect density and promote device performance.

\subsection{Effect of $\mathrm{MoS}_{2}$ layer}

Table 2 shows the PV performance under different temperature for both structure. The performance of PSCs were further simulated with increasing operating temperature up to $350 \mathrm{~K}$. These results shows better stability of the $\mathrm{MoS}_{2}$-based with respect to the basic structure. The $\mathrm{MoS}_{2}$-based PSC shows a decrease in the efficiency which from $13.13 \%$ to $12.28 \%(\Delta \mathrm{y} / \mathrm{y}=-6 \%)$ compared to reference cell which degraded from $13.93 \%$ to $12.67 \%(\Delta \mathrm{y} / \mathrm{y}=-9 \%)$. The improved stability of the $\mathrm{MoS}_{2}$-based is endorsed to the surface passivation of the perovskite layer provided by $\mathrm{MoS}_{2}$ which prevents the iodine migration from the perovskite into the Spiro-OMETAD and the formation of Au from the metal electrode to perovskite layer. Figure 6(a) shows the quantum efficiency (QE) curves for both structure which indicated the $\mathrm{MoS}_{2}$-based cell has a slightly high value in the 350-700nm range compared to the reference cell. Meanwhile, Figure 6(b) shows the Nyquist plot of the PSCs. The arcs at high-intermediate frequency are mainly attributed to the charge-transport resistance, (Rct) at the interface of FTO contact with the perovskite layer. 
Table 2. PV performance under different temperature

\begin{tabular}{|c|c|c|c|}
\hline & Performance & $\mathrm{T}=300 \mathrm{~K}$ & $\mathrm{~T}=350 \mathrm{~K}$ \\
\hline \multirow{4}{*}{$\begin{array}{c}\mathrm{FTO} / \mathrm{TiO}_{2} / \mathrm{CH}_{3} \mathrm{NH}_{3} \mathrm{PbI}_{3} / \mathrm{S} \\
\text { piro-OMETAD }\end{array}$} & $\mathrm{V}_{\mathrm{oc}}(\mathrm{V})$ & 0.969 & 0.869 \\
\hline & $\mathrm{J}_{\mathrm{sc}}\left(\mathrm{mA} / \mathrm{cm}^{2}\right)$ & 21.676 & 21.324 \\
\hline & $\mathrm{FF}(\%)$ & 66.295 & 68.388 \\
\hline & $\mathrm{y}(\%)$ & 13.93 & 12.67 \\
\hline \multirow{4}{*}{$\begin{array}{c}\mathrm{FTO} / \mathrm{TiO}_{2} / \mathrm{CH}_{3} \mathrm{NH}_{3} \mathrm{PbI}_{3} / \\
\mathrm{MoS}_{2} / \text { Spiro-OMETAD }\end{array}$} & $\mathrm{V}_{\mathrm{oc}}(\mathrm{V})$ & 0.983 & 0.870 \\
\hline & $\mathrm{J}_{\mathrm{sc}}\left(\mathrm{mA} / \mathrm{cm}^{2}\right)$ & 21.676 & 21.324 \\
\hline & $\mathrm{FF}(\%)$ & 61.650 & 66.200 \\
\hline & y $(\%)$ & 13.13 & 12.28 \\
\hline
\end{tabular}

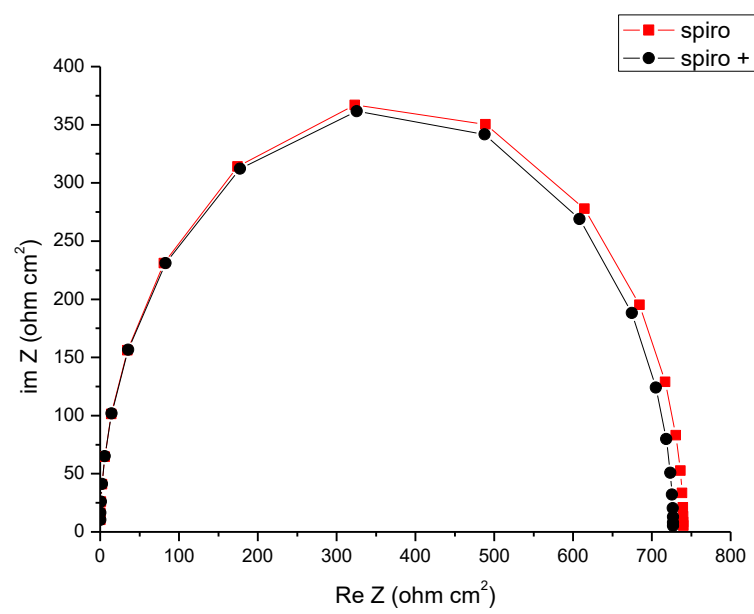

(a)

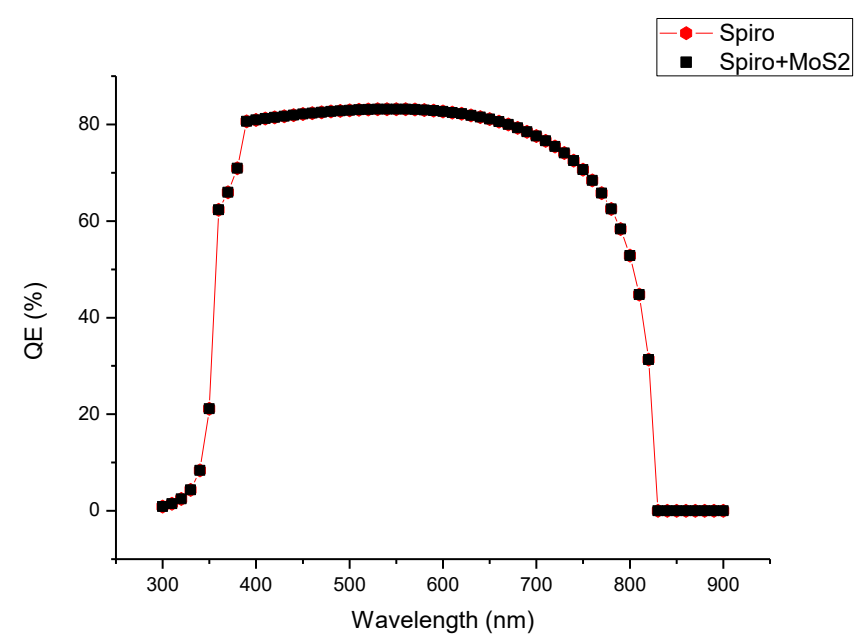

(b)

Figure 6. Quantum efficiency (QE) curves for both structure, (a) Nyquist plot with the basic parameters in Table 1, (b) Quantum efficiency characteristics

\section{CONCLUSION}

The simulation results shows that due to the high absorption coefficient, absorber layer up to 700nm is sufficient for decent performance device, and there is an optimal thickness for most certain operating condition. The use of $\mathrm{MoS}_{2}$ layer as an active layer been demonstrated in hybrid lead halide perovskite solar cells with $\mathrm{FTO} / \mathrm{TiO}_{2} / \mathrm{CH}_{3} \mathrm{NH}_{3} \mathrm{PbI}_{3} / \mathrm{MoS}_{2} / \mathrm{Spiro}-\mathrm{OMETAD}$ structure. Typical structure of PSCs without $\mathrm{MoS}_{2}$ have shown a $\mathrm{y}$ of $13.9 \%$ diminishing to $12.6 \%$ at different temperature condition. $\mathrm{MoS}_{2}$-based PSCs instead

Device simulation of perovskite solar cells with molybdenum disulfide as... (Ainon Shakila Shamsuddin) 
reached a $\mathrm{y}$ of $13.1 \%$ decreased to $12.3 \%$, proving the enhanced stability of the cell due to the presence of $\mathrm{MoS}_{2}$ layer as active layer. The results pave the way towards the implementation of $\mathrm{MoS}_{2}$ as a material able to boost shelf life which very useful for new material choice and optimization of HTMs.

\section{ACKNOWLEDGEMENTS}

The author would like to acknowledge and appreciate of KDU University College through the research grant with code KDURG/2017/1/004.

\section{REFERENCES}

[1] A. Kojima, K. Teshima, Y. Shirai, and T. Miyasaka, "Organometal halide perovskites as visible-ight sensitizers for photovoltaic cells," J. Am. Chem. Soc., vol. 131, no. 17, pp. 6050-6051, 2009.

[2] M. M. Lee, J. Teuscher, T. Miyasaka, T. N. Murakami, and H. J. Snaith, "Efficient Hybrid Solar Cells Based on Meso-Superstructured Organometal Halide Perovskites,” Science (80-. )., vol. 338, no. 6107, 2012.

[3] M. Liu, M. B. Johnston, and H. J. Snaith, "Efficient planar heterojunction perovskite solar cells by vapour deposition," Nature, vol. 501, no. 7467, pp. 395-398, Sep. 2013.

[4] H. Zhou et al., "Interface engineering of highly efficient perovskite solar cells," Science (80-.). vol. 345, no. 6196, pp. 542-546, 2014.

[5] G. Adam et al., "Solution processed perovskite solar cells using highly conductive PEDOT:PSS interfacial layer," Sol. Energy Mater. Sol. Cells, vol. 157, pp. 318-325, 2016.

[6] P. A. Basore, "Numerical modeling of textured silicon solar cells using PC-1D," IEEE Trans. Electron Devices, vol. 37, no. 2, pp. 337-343, 1990.

[7] P. P. Altermatt, "Models for numerical device simulations of crystalline silicon solar cells-A review," Journal of Computational Electronics, vol. 10, no. 3. pp. 314-330, 2011.

[8] A. Niemegeers and M. Burgelman, "Effects of the Au/CdTe back contact on IV and CV characteristics of $\mathrm{Au} / \mathrm{CdTe} / \mathrm{CdS} / \mathrm{TCO}$ solar cells," J. Appl. Phys., vol. 81, no. 6, pp. 2881-2886, 1997.

[9] R. Klenk, "Characterisation and modelling of chalcopyrite solar cells," Thin Solid Films, vol. 387, no. 1-2, pp. 135-140, 2001.

[10] F. Liu et al., "Numerical simulation: Toward the design of high-efficiency planar perovskite solar cells," Appl. Phys. Lett., vol. 104, no. 25, 2014.

[11] S. M. Iftiquar and J. Yi, "Numerical simulation and light trapping in perovskite solar cell," J. Photonics Energy, vol. 6, no. 2, p. 25507, 2016.

[12] M. Z. Mokhtar et al., "CH3NH3PbI3 films prepared by combining 1- and 2-step deposition: How crystal growth conditions affect properties," Phys. Chem. Chem. Phys., 2017.

[13] T. A. Berhe et al., "Organometal halide perovskite solar cells: degradation and stability," Energy Environ. Sci., vol. 9, no. 2, pp. 323-356, 2016.

[14] J. Burschka et al., "Tris(2-(1 H-pyrazol-1-yl)pyridine)cobalt(III) as p-type dopant for organic semiconductors and its application in highly efficient solid-state dye-sensitized solar cells," J. Am. Chem. Soc., vol. 133, no. 45, pp. 18042-18045, 2011.

[15] G. Divitini, S. Cacovich, F. Matteocci, L. Cinà, A. Di Carlo, and C. Ducati, "In situ observation of heat-induced degradation of perovskite solar cells," Nat. Energy, vol. 1, no. 2, p. 15012, 2016.

[16] E. L. Unger et al., "Hysteresis and transient behavior in current-voltage measurements of hybrid-perovskite absorber solar cells," Energy Environ. Sci., vol. 7, no. 11, pp. 3690-3698, 2014.

[17] L. Etgar et al., "Mesoscopic CH3NH3PbI3/TiO2 Heterojunction Solar Cells," J. Am. Chem. Soc., vol. 134, no. 42, pp. 17396-17399, 2012.

[18] G. E. Eperon, V. M. Burlakov, P. Docampo, A. Goriely, and H. J. Snaith, "Morphological control for high performance, solution-processed planar heterojunction perovskite solar cells," Adv. Funct. Mater. vol. 24, no. 1, pp. 151-157, 2014.

[19] S. Guarnera et al., "Improving the long-term stability of perovskite solar cells with a porous Al2O3 buffer layer," $J$. Phys. Chem. Lett., vol. 6, no. 3, pp. 432-437, 2015.

[20] M. Burgelman, P. Nollet, and S. Degrave, "Modelling polycrystalline semiconductor solar cells," Thin Solid Films, vol. 361, pp. 527-532, 2000.

[21] G. Niu, W. Li, F. Meng, L. Wang, H. Dong, and Y. Qiu, "Study on the stability of CH3NH3PbI3 films and the effect of post-modification by aluminum oxide in all-solid-state hybrid solar cells," J. Mater. Chem. A, 2014.

[22] B. El Cohen and L. Etgar, "Parameters that control and influence the organo-metal halide perovskite crystallization and morphology," Frontiers of Optoelectronics, vol. 9, no. 1. pp. 44-52, 2016.

[23] T. Minemoto and M. Murata, "Impact of work function of back contact of perovskite solar cells without hole transport material analyzed by device simulation," Curr. Appl. Phys., vol. 14, no. 11, pp. 1428-1433, 2014

[24] Saman Kohnehpoushi, Pariya Nazari, Bahram Abdollahi Nejand *, Mehdi Eskandari "MoS 2 : a Two Dimensional (2D) Hole-Transporting Materials for High Efficiency and Low-cost Perovskite Solar Cells," NANO-116755.R1, 2018 . 
[25] S. Two-dimensional, D. Jariwala, V. K. Sangwan, L. J. Lauhon, T. J. Marks, and M. C. Hersam, "Emerging Device Applications for Semiconducting Two-Dimensional Transition Metal Dichalcogenides," ACS Nano, vol. 8, no. 2, pp. 1102-1120, 2014.

\section{BIOGRAPHIES OF AUTHORS}
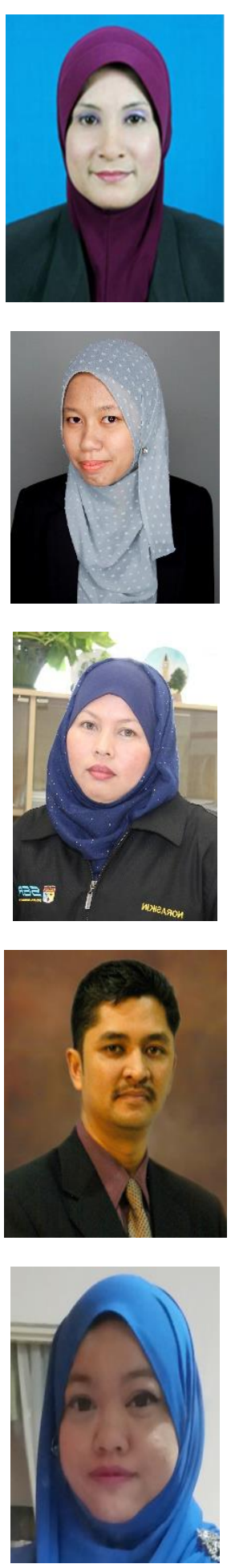

Ainon Shakila Binti Shamsuddin has graduated with a first degree in BEng. in Electrical Engineering (Power) from University of Technology Malaysia, Skudai, Malaysia, and Masters of Engineering Management from Universiti Teknologi Mara (UiTM). She has worked with Panasonic Compressor R\&D Sdn Bhd as a Senior Engineer for more than 13 years. Currently, she is a Lecturer in Electrical Power Engineering at the KDU University College Sdn Bhd. Her main area of research comprises Distributed Power Generation, Renewable Energy, Electrical Machines, Variable Speed Drives, Finite-Element Analysis and Design, Power-Electronic Converters, and Electric-Vehicle Traction Systems.

Puteri Nor Aznie Fahsyar received her MEng. Sc. in Microelectronics from University of Malaya, in 2012 and graduated in B. Eng. (Hons) Electrical from Universiti Teknologi Malaysia in 2007. Currently, she is pursuing his Ph.D. in Renewable Energy in National University of Malaysia while playing her role as lecturer in Electrical Power Engineering at the KDU University College. Her main area of research work are in the field of organic solar cells, perovskite and transition metal materials. Her interest also lies around the nanomaterials and renewable energy systems.

Norasikin is a Research Fellow/Senior Lecturer at Solar Energy Research Institute (SERI), Universiti Kebangsaan Malaysia. She obtained her PhD in Chemistry (Dye-sensitized Solar Cells) from University of Wales, United Kingdom in 2012. Her specialization is solar light energy conversion and advanced materials for solar cell. Her research is concerned on development of new solar cell technology related to the natural sensitizers' process of dyesensitized solar cell. This includes synthesis of natural dyes, absorption and desorption of dyes by oxide semiconductor materials and also photoelectrochemical properties of dye-sensitized solar cell (DSSC). She also involved in organic and perovskite solar cells projects. Her expertise includes renewable energy policy and the impact study of the technologies.

Ibrahim Bin Burhan has graduated with a first degree in BSc. in Electrical Engineering (Intrumentation \& Control) and Masters of Education (Technical Education) from University of Technology Malaysia, Skudai, Malaysia, Since 1999, he has been attached as a lecturer in the Department of Electrical Engineering at Polytechnic of Sultan Salahuddin Abdul Aziz Shah. He was transferred to the Department of Aircraft Maintenance in the year 2006 within the same polytechnic and transferred to Polytechnic of Banting Selangor (PBS) in 2016. His main area of research comprises Complex Assessment, Robotic, Programmable Logic Controller (PLC), Control Systems and Aircraft Maintenance.

Salina binti Mohmad obtained her Masters in Science (MSc.) in Microelectronics Systems Design from University of Southampton, UK in 2004. She completed her Bachelor Degree in Electrical and Electronics Engineering from Universiti Teknologi PETRONAS, Malaysia in 2002. Currently she is pursuing her PhD in Engineering studies in KDU University College. She is also a full time senior lecturer in School of Engineering, KDU University College. Her research interests are in Renewable Energy as well as Sensors Systems. 